\title{
Love's Labor's Lost: Sex and Art in Two Novels by Anthony Burgess
}

In the epilogue to his wide-ranging collection of literary essays, Urgent Copy, Anthony Burgess sketches the circumstances which preceded (and to a great extent precipitated) his belated blossoming as professional novelist and man of letters. "I went to the Gates of Hercules," he writes, "the sundered lips of Europe and Africa, to Deucalion's flood and Noah's. In other words, I was posted to Gibraltar."1 Here, on a rock colonized by the British but reeking of both its Spanish and Moorish heritage, the Catholic Burgess encountered finally a living reconciliation of the Catholic/Protestant dichotomy which had troubled his own Manchester youth. Protestant Britain, perched precariously on the foundations of two powerful alien cultures, had somehow forged these (and her own) into a diverse and yet oddly harmonious multi-culture-a place where, as Burgess says, Arabs discussed Aristotle on the colonnade of an Iberian University. This strange colony came to serve for Mr. Burgess as a proof, even a model, of the feasibility of "confluence." "In Gibraltar," he writes, "my muse seemed to have found what it was looking for in the way of a subject matter-a conflict that had turned into a confluence."2

Mr. Burgess likes to portray the universe as a "duoverse," that is, a cluster of contending opposites which agitate against moderation. "The thing we're most aware of in life," he writes, "is the division, the conflict of opposites-good, evil; black, white; rich, poor-and so on."3 And since living in the center of this conflict is, to use Mr. Burgess's illustration, like trying to picnic in the middle of a football field, we gravitate naturally (and gratefully) toward any ideology which is able to convince us that this conflict is actually an illusion, that in fact there is somewhere an ultimate unity in which all extremes resolve themselves. To this end the Church proffers God; socialism, the classless society; and the artist, his art.

"Art," according to Burgess, "is the organization of base matter into an illusory image of universal order." 4 The artist is an alchemist, drawing on the inherent disorder and dissonance of the human experience and somehow transmuting them into a dazzling display of order and harmony. Contending forces which divide our allegiances in the real world are tamed and reconciled in the artistic creation, or at least seem to be, and the illusion of unity is the final product of this creative process. 
Yet though most people, according to Burgess, are possessed by the need to unify, they generally accept solutions rather than work out their own. How many Calvinists are there, after all, for every Calvin; how many Marxists for each Marx? Only the sexual division, the thing that makes a man different and apart from a woman (and vice-versa), is actually resolvable on an individual and thoroughly active level. This ritual, grâce à Dieu, is the exclusive possession of no one class or profession-there is, one assumes, no sexual aristocracy-and it may serve the artist as well or as poorly as it does anyone else. But it is of particular importance in Burgess's novels about artists because, as another means of achieving confluence, sex is closely allied with the creative act. It is, in fact, consistently used to reflect the condition of the less democratic syntheses which his artist-characters pursue.

Sex and art, then, serve as two separate though related expressions of the same drive, and because Burgess's protagonists in Nothing Like the Sun and A Vision of Battlements resort frequently to both, the two provide a good perspective on the conflict and confluence theme which figures so prominently in the ever-burgeoning Burgess canon.

A Vision of Battlements is Mr. Burgess's first novel. Although not published until 1965, the book was written some 16 years earlier. "When the Easter vacation of 1949 arrived," Burgess writes in his introduction, "I was empty of music but itching to create. And so I wrote this novel. It filled up the vacation, kept me out of mischief, and also satisfied a vague curiosity I had always had: could I, for good or ill, compose an extended piece of prose without getting bored." A second, more submerged reason for the novel "was to see if I could clear my head of the dead weight of Gibraltar. I had lived with it so long that it still lay in my skull, a chronic migraine: a work of fiction seemed the best way of breaking it up, pulverizing it, sweeping it away."5

And indeed "the rock" looms like a threatening deity over the affairs of Sgt. Richard Ennis, Burgess's half-fictional protagonist who finds himself posted in wartime Gibraltar as instructor in the newly formed "Army Vocational and Cultural Corps." The unit is divided into two branches: the forward-looking "Vocational," which goes about training men to build a new world when the war is over; and the backward-looking "Cultural" (Ennis's), which is supposed to inculcate an appreciation for the arts, but languishes instead in the inattention of what C. P. Snow was to call the New Men. Ennis wants to make it in this new world, for his own sake as well as for his wife's (she eventually runs off with an American-the new world personified), but finds himself irresistibly attracted to the old: to his art, to the ancient culture of the Spanish and the Moors, and to his Spanish mistress, Concepción. 
Burgess's description of the dilemma is characteristically direct: "Ennis had become a manichee, at home in a world of perpetual war. It did not matter what the flags or badges were; he looked only for the essential opposition-Wet and Dry, Left Hand and Right Hand, Yin and Yang, X and Y. Here was the inevitable impasse, the eternal stalemate" (Vision, pp. 68-9). And down the line the alliances form. Ennis's English wife, Laurel, is cool, refined, aseptic; Concepción is rich, warm, fragrant. While Laurel is the England of the Norse gods and the briny sea, Concepción is Spain, the ancient mingling of Latin and Moorish cultures, the stronghold of the Catholic Church-not the defensive, displaced Catholicism of Ennis's (and Burgess's) Northern England, but the proud, entrenched faith of Mediterranean Europe. And while Ennis is portrayed as sexually impotent with his wife ("Really, you are impetuous"), he is seen to enjoy a quite satisfactory relationship with Concepción, the product of which, predictably enough, is conception. Laurel, off in England writing long and nagging letters to Ennis, excites little passion; Concepción, his dark and alluring mistress, is passion.

The dichotomy, of course, brings to mind Shakespeare, particularly the Shakespeare of the sonnets, who serves, if somewhat posthumously, as the subject of Burgess's Nothing Like the Sun. Fair England and dark Africa once more compete for the allegiance of the artist, and once more, it is the very delicate, refined beauty of the aristocratic North balanced against the rich and passionate allure of a black woman. In Nothing Like the Sun Concepción reappears as the dark lady, an East Indian woman of mysterious background whom Will woos and wins for his mistress; and Laurel's place is taken by young Harry (WH), Earl of Southampton, patron and sometime object of Will's hypergamous affections.

The important distinction between the two pairs, however, is not so much that the fair image turns male, but that the hostile/reverent attitude which characterized this relationship in A Vision takes on the added aspect of sexual attraction. With Laurel, Ennis is unable to achieve any sexual compatibility; rarely, in fact, does he think of her in sexual terms. But with young Harry, Will manages to express both his hostility and his admiration through the ambivalence of their homosexual relationship. Sex serves as a vengeance as well as a pleasure, and as a result, the role of the fair image in this novel becomes much more complex and much more vital.

Burgess carefully adumbrates the relationship which is to develop between Harry and the poet by inserting early in the narrative a number of passages which establish Will's homosexual leanings. When, as a boy, he fantasizes about life at sea, Will thinks of "spewing among rude and rough rascals made roaring lustful with salt beef and, a mere week at sea, cursing and raging in their fights over the ravaging of the soft white body of a boy, 
a boy refined and gentled with snippets of Ovid and maxims out of Seneca." And Will's response is "a dark excitement ... that guilt at once pounced on in a rearing wave to wash away." 6

Even in the context of his marriage, where Will soon tires of his conjugal prerogatives, Burgess reveals a latent but already strongly developed disposition in the young poet. He tells how, after the birth of a child, Anne would steal their young son's clothes and, "decked as a pretty page, she would taunt him and simper before him and say: 'Take me, master, in whatever way you have a mind to.' This would fill his whole head with beating blood, so that he was blind and went for her blindly. She was, he saw, hunting out corners of corruption in his soul which he had hardly guessed at before" (Nothing, p. 40). The dark goddess continues to dominate his thoughts and his aspirations, but a second current of desire runs along parallel throughout, the attraction to male youth and beauty. "Catch as catch can," a fortune teller advises him, "A black woman or a golden man" (Nothing, p. 15).

With the relationship which finally blossoms between Will and his aristocratic patron thus prefigured, it is no surprise when, on first meeting, the poet's eye is immediately drawn to Harry's physical beauty: the red pouting mouth, the fair white skin, the sparse golden beard. "There was something in his eyes that WS did not like-a slyness, an unwillingness to look boldly. But he was beautiful enough, there was no doubt of his beauty" (Nothing, p. 91). By the end of the scene, the attraction has become firmly established: "WS looked down bitterly on this Adonis, so languid, so satiated of all his world could give. He saw himself taking him and stripping him of his silk and jewels and then beating him till he cried. I will raise great weals on thy tender delicate skin, puppy" (Nothing, p. 94).

Interestingly, homosexuality figures prominently in $A$ Vision as well. As early as 1949 Burgess was apparently associating the creative impulse with the homosexual sensibility. Trapped in the artistic wasteland of the Army Vocational and Cultural Corps, Ennis finds himself drawing closer and closer to the epicene coterie of Sgt. Julian Agate, "ballet dancer, one-time Petrouchka praised by Stravinsky and patted by Diaghilev" (Vision, p. 18):

The little dinner parties they held were gay with talk, foot-touching under the table, covert hand-holding. As they sat at the snowy table in the Winter Gardens Restaurant, digesting a meal that was as near civilized as one could hope for in the early days of European peace, smoking, chaffing, giggling over coffee, Ennis often felt almost happy. The world of women was far; the cool flutes of the epicene voices were soothing him to a strange peace (Vision, p. 86). 
The lustrous Agate embodies the cultural and artistic values which the new world of Major Muir (head of the A.V.C.C.) and his associates threatens to destroy. Agate has all the effeminate mannerisms that the convention demands, and Burgess exploits them for comic relief. But clichés notwithstanding, the role is important because it establishes quite early in the canon of Burgess's work this identification between art and the epicene. When, later in the novel, Ennis finds himself caught in another heterosexual affair-again with an English woman, again unfulfilled-his thoughts turn to Agate: "He wished he were back in a billet with Julian, in the calm epicene atmosphere where lust could be transmuted into creative energy. ... . He felt cloddish, cheap, boorish, just as he had often felt in the presence of Laurel" (Vision, p. 148).

In the light of Burgess's concern with artistic synthesis, particularly synthesis as it carries over into sexual activity, homosexuality certainly seems a distortion of the drive to unite the male/female division. In A Vision, this is partially explained by the notion of channeling the energy which derives from the tension of conflict out of the natural heterosexual solution into the more demanding but ultimately more satisfying possibilities of art. The greater the sense of division, the more potent (and productive) the drive to unite it. When Ennis talks about transmuting lust into creative energy, it is to this that he is referring. The "calm epicene atmosphere" of Julian and his circle serves to dam the energy which might otherwise dissipate in lesser (i.e., sexual) activities.

But the relationship between the creative and the sexual impulse is much more complex than this simple equation of psychodynamics suggests, primarily because other factors enter into the process. For Ennis, as well as for Will, sexual excitement becomes almost a necessary condition for the creation of art. Time and again these artist/protagonists find themselves composing, often against their own will, at the height of their sexual passion. In the process of making love to a girl he has met, Ennis finds his mind having a mind of its own: "He kissed her again, holding the kiss, indeed waiting for her response. Excitement began to flood his body welling as blood wells from a razorcut. . . . He kissed her bared neck, unable to hold back words. 'I do love you, Lavinia. My darling, I do love you.' At the same time, his aloof brain worked out a passage of double fugue" (Vision, pp. 171-2). Sex and music, in fact, become for Ennis mutually productive. Just as passion stimulates the flow of his music, so music can bring on the other thing:

Yet, as he and his room-mate sat together in their billet, Ennis composing, Julian embroidering silk or darning socks, a sudden wave of desire, of a sort of intolerable homesickness for Concepción would come 
over him. This was especially when the heat of inspiration, by some deep law of sympathy, provoked sexual heat. Excited as a new theme appeared or an old theme began to develop new possibilities, his pulse would start to race, and his nostrils would be suffused with that maddening smell of musk, his ears would tickle with the softness of her loosened hair (Vision, p. 86).

The bond between the instincts becomes so close, in fact, that Ennis need only watch two flies copulate on the ceiling and his bountiful muse descends.

In a sense, sexual heat becomes the muse, the inspiration to create. This is certainly the case in Nothing Like the Sun, where the entire narrative is built up around the conviction that the sonnets Shakespeare wrote stemmed from his bisexual entanglements. WS the poet is torn between a dark lady and a fair youth, and the passion which each excites is the inspiration for the poems which flow from his pen. That the dark lady is a muse figure Burgess makes no bones about. The first line of the book, "It was all a matter of a goddess-dark, hidden, deadly, horribly desirable" (Nothing, p. 3), ushers in the magic of her presence. She exists in the poet's imaginationsurfacing often in dream-like fantasies-long before, as mistress, she actually appears in the narration. In one dream, the connection between the passion she arouses and the poetry she will inspire emerges forcefully:

He turned, ready to swoon, unwinking, at the vision. She was naked, gold, glowing, burnished, burning, the sun, all desire of him.

"I am altogether thine. Do thou take what is thine."

$\mathrm{Oh}$, his young heart. Oh, the giddiness, the mad beating. He fell before her, fell at her golden feet. She raised him with strong arms of gold. They fell into swansdown, behind curtains of silver silk. And there was the promise that when the moment came, and soon, too soon, it must come, he would be possessed of all time's secrets and his very mouth grow golden and utter speech for which the very gods waited and would be silent to hear (Nothing, p. 9).

But neither the homosexual nor the heterosexual relationship endures through the maturing of Shakespeare's own artistic abilities, and by the time he is ready to begin the period of the great tragedies both have virtually expired. Love ceases to be his goddess-fair or dark-and, simultaneously, love ceases to be his muse. The venereal disease which he contracts (Burgess speculating here) represents the product of his love, just as the miscarriage and death of Concepción in A Vision represent the end result of Ennis's love. Heterosexual love proves not only unproductive, as is the 
homosexual, but destructive, a force which is capable of inspiring the soul to create, but which in the process exacts a terrible price. The goddess is no longer one of love and sweet verse, as the early comedies certainly suggest, but an embodiment of the evil which shackles the lives of good men in the tragedies. Scabrous and near death, WS perceives that the disease which has come of his love is a metaphor for the evil that dominates all mankind, that "... the great white body of the world was set upon by an illness from beyond, gratuitous and incurable. And that even the name Love was, far from being the best invocation against it, often the very conjuration that summoned the mining and ulcerating hordes" (Nothing, p. 231). In both novels then the movement is away from this form of inspiration, and toward deeper and more personal wells of creative energy. Sexual love reveals itself to be far more destructive than it is procreative, and the division between man and woman, so alluring in its promise of synthesis, yields only to the confluence of the protagonist's art.

\section{NOTES}

1 (New York: Norton, 1968), p. 267.

2 Ibid., p. 268.

3 Ibid., p. 265.

4 Ibid.

5 A Vision of Battlements (New York: Norton, 1965), pp. 7-8.

6 Nothing Like the Sun (New York: Norton, 1964), p. 8.

POETRY / MORGAN, SCHMITZ, PASTAN, PAPE, CLARK, H O L D N, S I T H, B E NEDIKT

\section{Bean Money / Robert Morgan}

Back from the market late with

a watermelon and his bib-pocket full

of cash my father shoved a fist of back-pay 